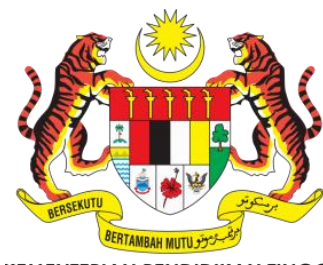

KEMENTERIAN PENDIDIKAN TINGGI
JOJAPS

eISSN 2504-8457

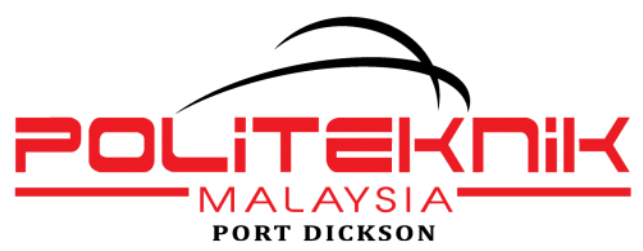

Journal Online Jaringan Pengajian Seni Bina (JOJAPS)

\title{
THE IMPLEMENTATION OF SAK ETAP AND THE EFFECT OF UMKM PREPARATION IN DEALING WITH MEA (ASEAN ECONOMIC SOCIETY) (CASE STUDY ON UMKM MEDAN \& BINJAI IN 2016)
}

\author{
Lily Karlina Nasution" Mayang Murni ${ }^{\text {b }}$, Ika Sari Dewic,Supriyanto ${ }^{\mathrm{d}}$ \\ a, b, c, d Politeknik LP3I Medan, Indonesia \\ lilykarlinanasution@gmail.com
}

\begin{abstract}
Micro Small and Medium Enterprises (UMKM) provide a strong contribution to the economy in Indonesia. In the fluctuating condition of Indonesia's economy, UMKM is able to prove its existence in the Indonesian economy. Moreover UMKM also contributed in reducing the number of productive unemployment in Indonesia. The potential of UMKM in Indonesia does not necessarily provide ease for Indonesia in facing the MEA. UMKM in Indonesia still have many obstacles, one of them is financial access that resulted in constraints in capital problems to develop the business. Most of UMKM entrepreneurs are unable to provide accounting information related to their business conditions. This condition is related to the financial information presented by UMKM in the financial statements, meaning that the quality of UMKM financial statements is not sufficient. This triggered the weakness of UMKM defense in facing competition of MEA which have started to enter Indonesia. The ASEAN Economic Community (MEA) is an economic integration agenda of ASEAN countries aimed at eliminating, or minimizing the constraints in conducting economic activities across regions, for example in the trade of goods, services and investments.
\end{abstract}

(C) 2017 Published by JOJAPS Limited

Keywords: Implementation of ETAP SAK, UMKM.

\section{Introduction}

The ASEAN Economic Community (MEA) is an economic integration agenda between ASEAN countries which is aimed at eliminating, or minimizing the constraints in conducting economic activities across regions, for example in the trade of goods, services and investments. Thus, in 2003, ASEAN leaders have agreed to build an "ASEAN society" by 2020. The establishment of the ASEAN Community 2015 is based on 3 pillars, the ASEAN Security Community, the ASEAN Economic Community, and ASEAN Socio-Cultural Community. The ASEAN Economic Community (AEC) 2015 will be directed to the establishment of a regional economic integration by reducing trade transaction costs, improving trade and business facilities, and enhancing the competitiveness of UMKM.

The potential of UMKM in Indonesia does not necessarily provide the ease for Indonesia in facing the MEA. UMKM in Indonesia has many obstacles and one of them is financial access. Based on the results of the Regional Development Institute survey (REDI, 2002) mentioned that there are 3 gaps encountered related to financial access for UMKM: (1) the aspect of formalities, because many UMKM do not have legal status; (2) business scale aspect, where often the credit scheme prepared by the banking system is not in line with the UMKM business scale and (3) information aspects, where banks do not know which UMKM should be financed, while UMKM also do not know what financing schemes are available in banking. Based on the gap above, the huge potentials owned by UMKM are often constrained by the capital problem to develop the business. This is accordance with the statement of Baas and Schrooten (2006). The reason for the low distribution of KUR is because the banks designated as KUR suppliers do not get adequate information related to the condition of UMKM so that they are very careful in giving lending. Most of UMKM entrepreneurs are unable to provide accounting information related to their business conditions. 
This condition is related to the financial information presented by UMKM in the financial statements, meaning that the quality of UMKM financial statements is not sufficient. This triggered the weakness of UMKM defense in facing competition of MEA which have started to enter Indonesia.

For that reason, the Financial Accounting Standards Board (DSAK) in 2009 has ratified the Accounting Standard for NonPublic Accountable Entities (SAK ETAP). The use of SAK ETAP is intended for entities without public accountability such as the entities that have no significant public accountability, and the entities that publish financial statements for general purposes for external users. SAK ETAP is an accounting standard that use for business entities that do not have public accountability, such as micro small and medium entrepreneurs (UMKM). SAK ETAP is more easily to understand and not as complex as General SAK. UMKM is expected to be able to do accounting bookkeeping to present financial statements so that it would be easier for UMKM entrepreneurs to get financing. Based on the problems above the main problem in this research is: "Implementation of SAK ETAP and Its Influence on Readiness of UMKM in Facing MEA".

\section{Review of Related Literature}

\section{Financial Statement}

Kieso (2010) explains that the financial statements are means of communicating key financial information to parties outside of the corporation. According to PSAK No.1 (2007, paragraphs 7-69) and PSAK No.2 (2007, paragraphs 9-16), the complete financial statements consists of balance sheet, income statement, changes in equity, cash flow statement and notes of the financial statements. According to the Basic Framework for the Preparation and Presentation of Financial Statements (2007, paragraph 9), the users of financial statements include current investors and potential investors, employees, lenders, suppliers and other business creditors, customers, governments, institutions, and communities. The purpose of the financial statements mentioned in SAK (2009) is to provide information on financial position, financial performance, and cash flows statement of an entity beneficial to a large number of users in economic decision making by anyone not in a position to request special financial statements to meet the certain information needs.

\section{Accounting Standards for Entities without Public Accountability (SAK ETAP)}

SAK ETAP issued by IAI is intended to provide convenience for small and medium scale entities. That IFRS-based SAK (General SAK) is intended for entities with significant public responsibilities and entities that engage in cross-border activities. These general SAK are complex to be understood and applied to most small and medium scale business entities in Indonesia. SAK ETAP provides many facilities for an entity compared to a General IFRS with more complex reporting requirements. Susanto and Yuliani (2012), said that the entity without public accountability is an entity that has no significant public accountability; and publish general purpose financial statements for external users. Thus external users can understand well and correctly the information provided in the financial statements, making it easier for the parties concerned to take decision related credit, funding or investment. The implementation of MEA will focus on 12 priority sectors, consisting of 7 (seven) sectors of goods (agriculture industry, electronic equipment, automotive, fishery, rubber-based industry, wood-based industry and textile) and 5 (five) service sectors (air transportation, health services, tourism, logistics, and the information technology industry or e-ASEAN).

\section{Micro Small and Medium Enterprises (UMKM)}

Micro small and medium enterprises (UMKM) in Indonesia are one of Indonesia's economic pillars beside cooperatives. UMKM are a strong business sector. The suspension of small micro enterprises (UMK) has proven as an economic safety net when many large companies are out of business, many UMKM still survive. In its development, UMKM in Medan need to get more serious attention in order to improve the ability of entrepreneurs to compete in larger markets. As the effort to boost the ability of UMKM, the government ratified Law no. 20 Article 7 paragraph 01, year 2008 on the growth of micro and small business climate. The law is structured with the intent to empower micro small and medium enterprises. (The Law of the Republic of Indonesia).

\section{RESEARCH METHODS}

\section{Research Stages}

The research stages are divided into 6 (six) stages described in the diagram below:

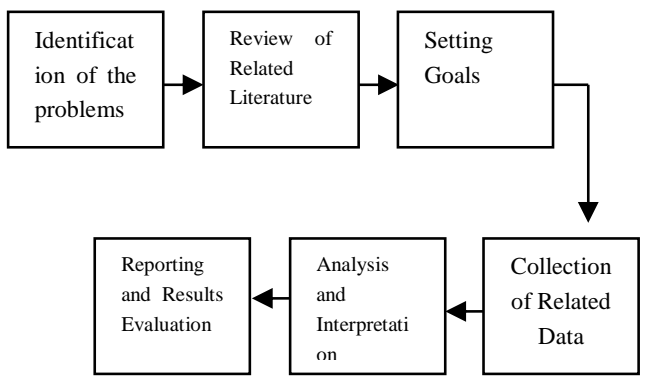

Figure 3.1 Research stages Diagram 


\section{Research sites}

The location of this research is small and medium enterprises group in Medan and Binjai in 2015. The Data of research is taken from financial report of UMKM and questioner.

\section{Variables Observed / measured}

The variables observed in this research are the implementation of SAK ETAP in the quality of UMKM financial report in Medan and its effect on the readiness in facing MEA. All financial statements of UMKM before using SAK ETAP is collected and subsequently the report will be improved by implementing SAK ETAP. The effect of the financial statements that have been accordance with SAK ETAP will be seen on the readiness of UMKM in facing the MEA by using questionnaires.

\section{Models Used}

The model used in this research:

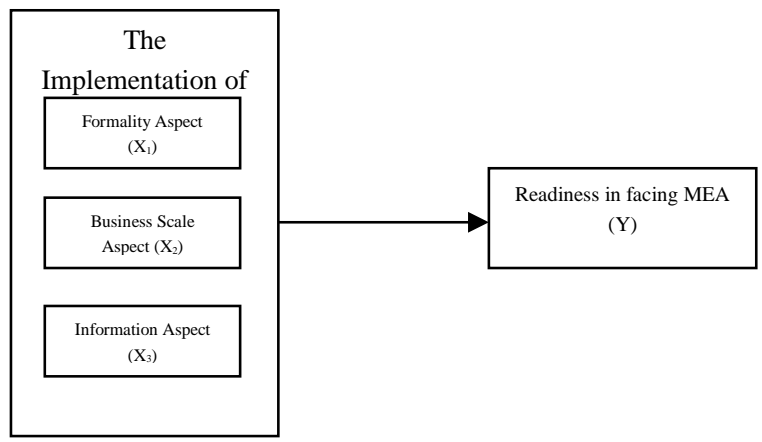

The regression equations in this research are:

$$
Y=\alpha+\beta_{1} X_{1+} \beta_{2} X_{2}+\beta_{3} X_{3}+\varepsilon
$$

Where: $\mathrm{Y}=$ Readiness in Facing MEA

$\mathrm{X} 1=$ Formality Aspect

$\mathrm{X} 2$ = Business Scale Aspects

X3 = Information Aspects

$\alpha=$ Constants

$\varepsilon=$ Error

\section{Research design}

This research design using quantitative descriptive process with the success indicator is precisely prediction of readiness of UMKM in facing MEA after implementation from SAK ETAP in its financial statement.

\section{Analysis Techniques and Data Collection}

Data collection techniques in this research are by using observation techniques, documentation and interviews.

The analysis in this research use descriptive statistic and Regression. Analytical tools used are:

\section{a. Validity test}

This test is used to determine the validity of data and reliability generated in this research to test whether the list of questions in this questionnaire is valid or not. It can be seen from the coefficient effect obtained by using the Product Moment technique that calculates each question with a total score. The variable stated to be valid if the validity test of the researcher is significant; the $r$-calculate value is bigger than the $r$ table value (Ghozali, 2009).

\section{b. Reability Test}

Reliability is a measuring tool to measure a questionnaire which is a variables survey. Testing is done by calculating Cronbach Alpha from each variable. Instruments used in these variables are stated to be reliable if the value of Cronbach Alpha $(\alpha)$ is more than 0.6.

\section{c. R-Square Test (R2)}

R2 Test is used to measures how far the model's ability explains the dependent variable (Ghozali, 2009). The magnitude of coefficient is from 0 to 1 , if it is closer to 0 , the influence of all the independent variables became smaller, if the magnitude of the determination coefficient $\left(\mathrm{R}^{2} \mathrm{Test}\right)$ approaches 1 the influence of independent variables become greater. 


\section{RESULTS AND DISCUSSION}

\section{Sample Research}

The sample of this research is taken from the assisted UMKM located in Medan and Binjai. A total of 15 questionnaires have been distributed and as the results there are 10 Questionnaires returned and 2 of them were incomplete and the rest did not return.

Table 5.1 Sampling

\begin{tabular}{clc}
\hline No & \multicolumn{1}{c}{ Description } & Amount \\
\hline $\mathbf{1}$ & Sample from Medan and Binjai & 15 \\
$\mathbf{2}$ & Un-returned questionnaires & $(5)$ \\
$\mathbf{3}$ & Incomplete questionnaires & $(2)$ \\
& Amount of UMKM that meet the requirement & $\mathbf{8}$ \\
\hline
\end{tabular}

Source: The result of the data

\section{Description of Statistics}

Sample distribution based on business location in Medan and Binjai. Based on the total of respondents, $80 \%$ of respondents are graduated from high school/vocational school and $20 \%$ of respondents do not go to high school /vocational school. Based on the type of business, $80 \%$ of respondents run trading business and $20 \%$ others run goods production business (manufacturing).

Business groupings based on the size of their business as much as 37.5\% included into micro business, $37.5 \%$ entered into small business group and $25 \%$ other into the middle business group. While based on the age of the business establishment there are $25 \%$ establish within the period of 5-10 years, $25 \%$ of businesses establishment within 10-15 years, 37.5\% establish within 16-20 years, and $12.5 \%$ establish within 21-25 years. From the total respondents observed: $25 \%$ of respondents stated that the financial statements become unimportant and important, while the remaining $50 \%$ of respondents stated that the financial statements are very important. Meanwhile, if it is viewed from the level of urgency of financial statements in business, almost all respondents expressed unfamiliarity with the standard financial statements for UMKM or in accordance with SAK-ETAP. It is because that the level of information and socialization/info about SAK ETAP received is still relatively limited or not available at all.

\section{The Implementation of SAK ETAP}

From the results of research conducted on the respondents note that the process of financial recording and reporting is still manually using a daily bill, paper that has been given a format where there are records of sales and production, or use the cash in and out book which is sale on public. The financial records procedure for some respondents' are only records into a record book for every order, purchase, expense or sales transaction. Even some of them are only use summing system for the cash in and cash out on each day. The respondents have been known about the information on the implementation of SAK ETAP after the researchers do research on their business. Each business is equipped with the knowledge about the urgency of the standardized financial statements and the process of creating a structured financial report for long term business continuity in the future.

\section{The Effect of Implementation of SAK ETAP on UMKM Readiness in Facing MEA (ASEAN Economic Community)}

Implementation of SAK ETAP in UMKM is seen from the aspect of the formalities of the financial statements produced, the scale of business and the adequate information on standard financial reporting. These three aspects are associated with the readiness of UMKM in facing larger and wider trade competition that is the ASEAN Economic Community. The relationship between the three independent and dependent variables is shown in the summary model table below:

Tabel 5.2 Model Summary ${ }^{\mathrm{b}}$

\begin{tabular}{|l|r|r|r|r|}
\hline Model & $\mathrm{R}$ & R Square & Adjusted R Square & Std. Error of the Estimate \\
& & & & \\
\hline 1 & $.878^{\mathrm{a}}$ & .771 & .600 & .32733 \\
\hline
\end{tabular}

a. Predictors: (Constant), X3, X2, X1

b. Dependent Variable: Y

Based on the value of Adjusted R Square (R2) of 0.600 means that $60 \%$ of variables Readiness in facing MEA can be explained by independent variable Formality Aspect (X1), Business Scale Aspect (X2) and Information Aspect (X3). The rest of 40\% is explained by other factors outside the model. Meanwhile, for the significance simultaneously Test (F-Test) between the influence of the three independent variables: Formality Aspect (X1), Business Scale Aspect (X2) and Information Aspect (X3) to the dependent variable Readiness in facing MEA (Y), shown by ANNOVA table: 
Tabel 5.3 ANOVA ${ }^{\mathrm{a}}$

\begin{tabular}{|l|r|r|r|c|l|}
\hline Model & Sum of Squares & df & Mean Square & F & Sig. \\
\hline Regression & 1.446 & 3 & .482 & 4.500 & $.090^{\mathrm{b}}$ \\
1 Residual & .429 & 4 & .107 & & \\
Total & 1.875 & 7 & & & \\
\hline
\end{tabular}

a. Dependent Variable: Y

b. Predictors: (Constant), X3, X2, X1

Anova Test or F Test produce the F- calculate value of 4.500 with a significance level of 0.090 . Because the level of significance is greater than 0.05 it can be stated that independent variable: Formality Aspect (X1), Business Scale Aspects (X2) and Information Aspect (X3) simultaneously/entirety do not affect the dependent variable Readiness in facing MEA (Y). It is because, the respondents who become the research samples more focused on business continuity based on experience to face challenges not only based on financial reporting and standardized accurate financial information. The test is done partially for each independent variable: Formality Aspect (X1), Business Scale Aspect (X2) and Information Aspect (X3) to see its effect on dependent variable Readiness in facing MEA (Y). Partial test or test on each independent variable to dependent variable seen from T-Test in the coefficient table below:

Tabel 5.4 Coefficients ${ }^{\mathrm{a}}$

\begin{tabular}{|c|c|c|c|c|c|c|c|}
\hline \multirow[t]{2}{*}{ Model } & \multicolumn{2}{|c|}{$\begin{array}{l}\text { Unstandardized } \\
\text { Coefficients }\end{array}$} & \multirow{2}{*}{$\begin{array}{c}\begin{array}{c}\text { Standardized } \\
\text { Coefficients }\end{array} \\
\text { Beta }\end{array}$} & \multirow[t]{2}{*}{$\mathrm{t}$} & \multirow[t]{2}{*}{ Sig. } & \multicolumn{2}{|c|}{$\begin{array}{c}95.0 \% \\
\text { Confidence } \\
\text { Interval for B }\end{array}$} \\
\hline & B & $\begin{array}{l}\text { Std. } \\
\text { Error }\end{array}$ & & & & $\begin{array}{l}\text { Lower } \\
\text { Bound }\end{array}$ & $\begin{array}{l}\text { Upper } \\
\text { Bound }\end{array}$ \\
\hline (Constant) & 3.143 & 1.710 & & 1.838 & .140 & -1.604 & 7.890 \\
\hline $\mathrm{X} 1$ & -.214 & .420 & -.313 & -.511 & .636 & -1.379 & .951 \\
\hline $\mathrm{X} 2$ & -.714 & .350 & -1.152 & & .111 & -1.686 & .257 \\
\hline X3 & $\begin{array}{r}1.003 \mathrm{E}- \\
013\end{array}$ & .327 & .000 & .000 & 1.000 & -.909 & .909 \\
\hline
\end{tabular}

a. Dependent Variable: Y

The coefficient table above illustrates how the influence for each independent variable to the dependent variable in this research. The Formality Aspect (X1) variable has a sig value of $0.636>\alpha(0.05)$ with a t value of -0.511 meaning that the Formality Aspect (X1) has no effect on Readiness of UMKM in Facing MEA (Y), even this variable has negative direction of influence or opposite each other. The Business Scale Aspect $(\mathrm{X} 2)$ variable has a value of $0.111>\alpha(0,05)$ with $t$ value of $-2,041$ meaning that business scale aspect (X2) variable has no effect to Readiness of UMKM in Facing MEA (Y), even this variable has negative influence direction or opposite. Meanwhile, the Information Aspect (X3) variable has a sig value of $1,000>\alpha(0.05)$ with a t value of 0,000 meaning that the Information Aspect(X3) has no effect on Readiness of UMKM in Facing MEA (Y).

\section{CONCLUSION}

The implementation of SAK ETAP in UMKM financial statements is not seen in the respondents of this research. The financial statements are still using incoming and outgoing cash books. This means that the level of the financial statement formality not be urgency in business continuity according to the respondents. The influence of SAK ETAP implementation on Readiness of UMKM in facing MEA seen from three aspect such as formality aspect of financial report, business scale aspect and information aspect. From these three aspects, it is known that the implementation of SAK ETAP does not affect simultaneously to the readiness of UMKM in facing MEA. While partially these three aspects also have no effect on the readiness of UMKM in facing the MEA.

\section{Suggestion}

The UMKM entrepreneurs should make financial reports in accordance with SAK ETAP so that their financial cycles are recorded and can be reported properly, because the financial statements can be use as the decision-making reference for the progress of UMKM. 


\section{References}

Muas, Muhammad. 2014. Jurus Jitu Koperasi dan UKM dalam Menghadapi MEA 2015. Universitas Gunadarma Rudiantoro Rizki, Sylvia Veronica Siregar. 2012. Kualitas Laporan Keuangan UMKM Serta Prospek Implementasi SAK ETAP. Jurnal Akuntansi dan Keuangan Indonesia

Susanto, Barkah \& Nur Laila Yuliani. 2012. Prospek Implementasi Sak ETAP Berbasis Kualitas Laporan Keuangan UMKM. Universitas Muhammadiyah Malang

Supriyanto (2014), Analisis Pengaruh Kinerja Keuangan Terhadap Pertumbuhan Laba Perbankan di Bursa Efek Indonesia, Jurnal Ilman 1 (1), 69-82|vol:1 issue |2014.

www.bps.go.id

www.kadin-indonesia.or.id 